\title{
Peningkatan Kualitas Pembelajaran Pkn Melalui Metode Think Pair Share (TPS) Berbasis CD Pembelajaran Siswa Kelas IV SD Negeri 04 Muara Kemumu
}

\author{
Marsolena \\ SD Negeri 04 Muara Kemumu \\ fajriananda153@gmail.com
}

\begin{abstract}
This study aims to describe the improvement of teacher skills, student activities, and student learning outcomes in class IV Civics learning at SD Negeri 04 MuaraKemumu through a Think Pair Share (TPS) model based on learning CDs. The method used in this study is classroom action research. This classroom action research consists of three cycles, with stages in each cycle, namely planning, implementation, observation, and reflection. The method used in this study is classroom action research. Data collection techniques used are observation and tests. Observation is done by observing the subject of the study, while the test technique is used to determine the learning outcomes achieved by students. This research was conducted at 04 Public Elementary School MuaraKemumu. The research subjects were teachers and students of class $I V$-A with a total of 38 students consisting of 19 male students and 19 female students. Research variables are teacher skills, student activities, and student learning outcomes. The results showed that from the teacher's skills in the first cycle the score was 22 in sufficient categories, the second cycle increased to 26 in attitudes and behaviors that were in accordance with PKn values
\end{abstract}

Keywords:PKn, Think Pair Share (TPS) Method, Learning CD.

\section{Pendahuluan}

Pendidikan Kewarganegaraan bertujuan untuk membentuk warga negara yang baik, kreatif, bertanggung jawab, cerdas, kritis, dan partisipatif. Berdasarkan refleksi melalui observasi dan analisis dokumen yang dilakukan peneliti dengan tim kolaborator, dapat dinyatakan bahwa pembelajaran PKn kelas IV masih belum optimal. Hasil pengamatan pada siswa kelas IV SD Negeri 04 Muara Kemumu menunjukkan beberapa permasalahan, yaitu guru belum menerapkan model pembelajaran yang kreatif dan inovatif dalam mengelola kegiatan pembelajaran. Guru hanya meminta siswa untuk membaca bacaan yang terdapat di buku paket lalu menjawab pertanyaan yang ada dan adanya anggapan dari diri para siswa bahwa pelajaran PKn merupakan mata pelajaran yang tidak menarik dan identik dengan hafalan. Siswa kurang aktif dalam pembelajaran, dikarenakan kurang termotivasi untuk mengikuti pembelajaran. Maka hasil refleksi tersebut dapat berbanding lurus dengan hasil belajar siswa, lebih dari 50\% siswa di kelas IV SD Negeri 04 Mauara Kemumu belum memenuhi kriteria ketuntasan dengan nilai 
minimal 62. Sehingga perlu adanya pembenahan dengan menerapkan model yang inovatif.

Model pembelajaran Think-Pair-Share (TPS) merupakan salah satu jenis model pembelajaran kooperatif yang dirancang untuk mempengaruhi pola interaksi siswa. Strategi Think-Pair-Share ini berkembang dari penelitian belajar kooperatif dan waktu tunggu. Pertama kali dikembangkan oleh Frang Lyman dan koleganya di Universitas Maryland sesuai yang dikutip Arends (1997), menyatakan bahwa ThinkPair-Share merupakan suatu cara yang yang efektif untuk membuat variasi suasana pola diskusi kelas. Dalam penelitian ini digunakan CD Pembelajaran sebagai media pembelajaran dengan model Think Pair Share (TPS) untuk meningkatkan prestasi belajar siswa. Tampilan menu dibuat semenarik mungkin dengan menggunakan desain warna dan suara sehingga diharapkan akan tercipta suasana pembelajaran yang segar (fresh) dan menyenangkan (fun).

Maka dengan pemanfaatan media CD pembelajaran, pelaksanaan model pembelajaran Think Pair Share (TPS) berbasis CD pembelajaran akan meningkatkan minat siswa mengikuti pembelajaran PKn, membuat siswa untuk terlibat secara aktif dalam proses pembelajaran, mengembangkan pengetahuan secara mandiri, sikap dan keterampilan siswa sehingga dapat meningkatkan aktivitas dan prestasi belajar siswa.

Berdasarkan permasalahan tersebut peneliti mengungkapkan beberapa rumusan masalah dalam penelitian ini yaitu: a. Apakah melalui model Think Pair Share (TPS) berbasis CD pembelajaran dapat meningkatkan keterampilan guru dalam pembelajaran PKn kelas IV SD Negeri 04 Muara Kemumu? b. Apakah melalui model Think Pair Share (TPS) berbasis CD pembelajaran dapat meningkatkan aktivitas siswa dalam pembelajaran PKn kelas IV SD Negeri 04 Muara Kemumu? c. Apakah melalui model Think Pair Share (TPS) berbasis CD pembelajaran dapat meningkatkan hasil belajar pembelajaran PKn siswa kelas IV SD Negeri 04 Maura Kemumu?. Sehingga, tujuan dalam penelitian ini yaitu mendeskripsikan peningkatan keterampilan guru, aktivitas siswa, dan hasil belajar siswa dalam pembelajaran PKn kelas IV SD Negeri 04 Muara Kemumu melalui model Think Pair Share (TPS) berbasis CD pembelajaran.

\section{Metode}

Jenis penelitian ini adalah penelitian kualitatif. Metode penelitian dalam penelitian ini adalah penelitian tindakan kelas (PTK). Penelitian ini merupakan suatu proses yang dinamis meliputi aspek perencanaan, tindakan, observasi dan refleksi yang merupakan langkah berurutan dalam satu siklus yang berhubungan dengan siklus berikutnya. Pada Siklus I terdiri dari, rencana, pelaksanaan, dan Refleksi. Pada siklus I ini merupakan refleksi yang akan kami gunakan dalam melihat kekurangan dan kelebihan yang memungkin timbul pada perbaikan pembelajaran, sehingga dapat kami temukan beberapa kekuatan dan kelemahan pada diri peneliti.

Berdasarkan faktor-faktor kurang berhasilnya pembelajaran PKN yang telah dilaksanakan maka peneliti merancang rencana secara umum dalam melaksanakan perbaikan pembelajaran materi. Adapun tahapan-tahapan perencanaan perbaikan pembelajaran sebagai berikut : 1) Membuat rencana perbaikan pembelajaran secara tertulis yang berisi langkah-langkah pelaksanaan pembelajaran yang sekiranya siswa dapat dengan mudah mengikuti pembelajaran. 2) Menyiapkan lembar observasi yang merupakan hasil kesepakatan antara peneliti dengan teman sejawat yang bertindak sebagai selaku pengamat. 3) Membuat lembar kerja kelompok untuk mengetahui tingkat keberhasilan pembelajaran siswa. 4) Mengadakan tanya jawab mengenai hal-hal yang berhubungan dengan materi. 5) Siswa mengerjakan soal postes. 6) Secara bersama-sama siswa membuat kesimpulan hasil belajar. 


\section{Partisipan}

Subjek penelitian adalah siswa SD Negeri 04 Muara Kemumu Kabupaten Kepahiang kelas IV yang berjumlah 38 siswa terdiri dari 19 perempuan dan 19 laki-laki. Karakteristik siswa kelas IV SD Negeri 04 Muara Kemumu tahun pelajaran 2013/2014 ini sangat hiterogen, di kelas IV ini tingkat kecerdasan siswa tidak merata, ada yang aktif dan juga ada yang pasif.

\section{Instrumen}

Instrumen yang digunakan adalah tes dalam bentuk tes objektif yaitu soal pilihan ganda sebanyak dari 25 butir dengan 4 pilihan jawaban (a,b,c,d). Instrumen yang digunakan berisikan tentang materi nilai-nilai juang dalam Pancasila bagi kelas IV semester II SD Negeri 04 Muara Kemumu tahun pelajaran 2013/2014.

\section{Teknik Pengumpulan Data}

Teknik pengumpulan data yang digunakan dalam penelitian ini adalah observasi dan tes. Kegiatan observasi dilakukan pada saat pelaksanaan tindakan yang diobservasi aktivitas siswa dalam belajar. Sedang kan tes terdiri dari, pretes, LKS dan posttest.

\section{Teknik Analisis Data}

Teknik analisis data pada penelitian ini dimulai dengan menelaah seluruh data yang tersedia dari observasi awal, pelaksanaan tindakan, observasi, evaluasi, dan refleksi pada siklus I. Kemudian ditarik kesimpulan untuk selanjutnya dilakukan tindakan pada silkus II, pada siklus II juga diperoleh data dari pelaksanaan, observasi, evaluasi, dan refleksi. Teknik analisa data dengan menggunakan Uji Ketuntasan Belajar yaitu: nilai siswa yang $>7$ dinyatakan tuntas belajar sedangkan nilai siswa < 7 dinyatakan belum tuntas belajar. Bagi siswa yang belum tuntas belajar harus mengulang atau mengikuti siklus berikutnya dan harus sampai tuntas belajarnya.

\section{Hasil}

Adapun data yang diperoleh dalam penelitian ini, disajikan pada tabel 1.

Tabel 1 Tabel Peningkatan Keterampilan Guru, Aktivitas Siswa Dan Hasil Belajar Siswa.

\begin{tabular}{lccccccccc}
\hline \multirow{2}{*}{ Aspek/ Siklus } & \multicolumn{3}{c}{ Keterampilan Guru } & \multicolumn{3}{c}{ Aktivitas Siswa } & \multicolumn{3}{c}{ Hasil Belajar Siswa. } \\
\cline { 2 - 10 } & 1 & 2 & 3 & 1 & 2 & 3 & 1 & 2 & 3 \\
\hline Skor & 24 & 32 & 37 & 24,6 & 31,3 & 34,1 & 65,6 & 70,38 & 77,88 \\
\hline $\begin{array}{l}\text { Presentase } \\
(\%)\end{array}$ & $60 \%$ & $80 \%$ & $92,5 \%$ & - & - & - & $55,55 \%$ & $75 \%$ & $86,11 \%$ \\
\hline Kualifikasi & Cukup & Baik & $\begin{array}{c}\text { Sangat } \\
\text { Baik }\end{array}$ & Cukup & Baik & $\begin{array}{c}\text { Sangat } \\
\text { Baik }\end{array}$ & Cukup & Baik $\begin{array}{c}\text { Sangat } \\
\text { Baik }\end{array}$
\end{tabular}

Berdasarkan tabel di atas dapat dilihat hasil skor dan presenntase kenaikan pada aspek keterampilan guru, aktivitas siswa dan hasil belajar siswa yang meningkat dengan menerapkan metode Think Pair and Share (TPS) berbasis CD Pembelajaran dalam pembelajaran PKn kelas IV di SD Negeri 04 Muara Kemumu.

\section{Pembahasan}

Penerapan pendekatan TPS berbasis CD Pembelajaran mampu meningkatkan keterampilan guru dalam pembelajaran PKn kelas IV SD Negeri 04 Muara Kemumu. Hal ini dibuktikan dengan hasil penelitian yaitu pada siklus I jumlah skor yang 
diperoleh adalah 24 dengan persentase $60 \%$ dan kualifikasi cukup. kemudian meningkat pada siklus II menjadi 32 dengan persentase $80 \%$ dan kualifikasi baik. Dan di akhir siklus mengalami puncak dengan perolehan skor 37, persentase $92,5 \%$ dan kualifikasi sangat baik.

Penerapan pendekatan TPS berbasis CD Pembelajaran mampu meningkatkan aktivitas siswa dalam pembelajaran PKn kelas IV SD Negeri 04 Muara Kemumu. Hal ini dibuktikan dengan hasil penelitian yaitu pada siklus I perolehan rata-rata skor siswa adalah 24,6 dengan kualifikasi cukup. Kemudian meningkat pada siklus II dengan perolehan rata-rata skor 31,3, dan kualifikasi baik. Pada siklus III kembali meningkat dengan perolehan rata-rata skor 34,1, dan kualifikasi sangat baik.

Penerapan pendekatan TPS berbasis CD Pembelajaran mampu meningkatkan hasil belajar siswa. Hal ini dibuktikan dengan hasil penelitian yaitu ada siklus I rata-rata nilai siswa adalah 65,6 dengan persentase ketuntasan sebesar 55,55\% dan tingkat keberhasilan sedang. Kemudian pada siklus II meningkat ditunjukkan oleh nilai rata-rata siswa menjadi 70,38 dengan persentase $75 \%$ dan tingkat keberhasilan tinggi. Dan pada siklus III mengalami peningkatan kembali ditunjukkan dengan nilai rata-rata siswa menjadi 77,88 dengan persentase ketuntasan sebesar $86,11 \%$ dan tingkat keberhasilan sangat tinggi.

\section{Kesimpulan}

Dalam penelitian ini diperoleh kesimpulan bahwa dengan menerapkan pendekatan TPS berbasis CD pembelajaran dalam pembelajaran PKn kelas IV SD Negeri 04 Muara Kemumu dapat meningkatkan keterampilan guru, meningkatkan aktivitas siswa dalam pembelajaran dan meningkatkan hasil belajar siswa.

\section{Saran}

Dalam penelitian ini penulis memberikan beberapa saran, yaitu:

Sebaiknya guru menerapkan keterampilan dasar mengajar secara optimal dan kreatif dalam merancang pembelajaran yang menyenangkan dan bermakna pada mata pelajaran PKn salah satunya dengan menerapkan pendekatan TPS berbasis metode permainan.

Sebaiknya guru memotivasi dan mengarahkan siswa untuk belajar dengan aktif, antusias, dan kreatif menyalurkan bakat dan potensinya dalam pembelajaran PKn sehingga hasil belajar akan terus meningkat lebih baik.

Pendekatan TPS berbasis metode permainan dapat meningkatkan hasil belajar siswa sehingga baik diterapkan pada mata pelajaran PKn pokok bahasan "Nilai-nilai Juang dalam Perumusan Pancasila" dan juga mata pelajaran lain yang sesuai dengan TPS berbasis metode permainan.

\section{Referensi}

BNSP.2006.Standar Isi KTSP.Jakarta:Depdiknas.

Depdiknas.2004.PeningkatanKualitasPembelajaran.Jakarta:Direktorat

Daryanto.2003.Belajar dan Faktor-Faktor yang mempengaruhinya. Jakarta: Rineka Cipta.

Jhonson. 2010. Teori Belajar dan Pembelajaran. Jogjakarta: AR-Ruzz Media.

Hamadani. 2001.Strategi Belajar Mengajar. Bandung: Maulana. 
Pembinaan Pendidikan Tenaga Kependidikan dan Ketenagaan PerguruanTinggi

Solehin, H. 2012. Contextual Teaxhing Learning (CTL). http://hamdani.blogspot.com/2012_04_01_archive.html. Diakses: 18 Oktober 2012 